\title{
Experimental Determination of the Mechanical Properties and Deformation Constants of Mórágy Granitic Rock Formation (Hungary)
}

\author{
M. Davarpanah • G. Somodi • L. Kovács • B. Vásárhelyi
}

Received: 20 October 2019/Accepted: 26 January 2020/Published online: 3 February 2020

(C) The Author(s) 2020

\begin{abstract}
Determination of the mechanical behaviour of intact rock is one of the most important parts of any engineering projects in the field of rock mechanics. The most important mechanical parameters required to understand the quality of intact rock are Young's modulus $(E)$, Poisson's ratio $(v)$, the strength of rock $\left(\sigma_{\mathrm{c}}\right)$ and the ratio of Young's modulus to the strength of rock known as modulus ratio $\left(M_{\mathrm{R}}\right)$, which can be used for calculations. The particular interest of this paper is to investigate the relationship between these parameters for Hungarian granitic rock samples. To fulfil this aim, Modulus of elasticity $(E)$, Modulus of rigidity $(G)$, Bulk modulus $(K)$ and the modulus ratio $\left(M_{\mathrm{R}}=E / \sigma_{\mathrm{c}}\right)$ of 50 granitic rock samples collected from Bátaapáti radioactive waste repository were examined. Fifty high-precision uniaxial compressive tests were conducted on strong $\left(\sigma_{\mathrm{c}-}\right.$ $>100 \mathrm{MPa}$ ) rock samples, exhibiting the wide
\end{abstract}

M. Davarpanah $(\bowtie) \cdot$ B. Vásárhelyi

Department of Engineering Geology and Geotechnics,

Budapest University of Technology and Economics,

Budapest, Hungary

e-mail: mortaza.davarpanah@gmail.com

B. Vásárhelyi

e-mail: vasarhelyi.balazs@epito.bme.hu

G. Somodi · L. Kovács

RockStudy Ltd., Pecs, Hungary

e-mail: somodigabor@komero.hu

L. Kovács

e-mail: kovacslaszlo@komero.hu range of elastic modulus $(E=57.425-88.937 \mathrm{GPa})$, uniaxial compressive strength $\left(\sigma_{\mathrm{c}-}\right.$ $=133.34-213.04 \mathrm{MPa})$ and Poisson's ratio ( $v=0.18-0.32)$. The observed value $\left(M_{\mathrm{R}}=326-597\right)$ and mean value of $M_{\mathrm{R}}=439.4$ are compared with the results of similar previous researches. Moreover, the statistical analysis for all studied rocks was performed and the relationship between $M_{\mathrm{R}}$ and other mechanical parameters such as maximum axial strain $\left(\varepsilon_{\mathrm{a}, \max }\right)$ for studied rock samples was discussed. Finally, the validity of the proposed mathematical model by Palchik (Geomech Geophys Geo-energy Geo-resour 6:1-12, 2019) for stress-strain behaviour of granitic rock samples was investigated.

Keywords Uniaxial compressive test - Modulus of elasticity $(E) \cdot$ Modulus of rigidity $(G) \cdot$ Bulk modulus $(K) \cdot$ Modulus ratio $\left(M_{\mathrm{R}}\right) \cdot$ Maximum axial strain $\left(\varepsilon_{\mathrm{a}, \max }\right) \cdot$ Mórágy granite formation $\cdot$ Mathematical model

\section{Introduction}

Rock engineering properties are considered to be the most important parameters in the design of ground works. Two important mechanical parameters, uniaxial compressive strength $\left(\sigma_{\mathrm{c}}\right)$ and elastic modulus of rock $(E)$ should be estimated correctly. There are different empirical relations between $\sigma_{\mathrm{c}}$ and 
$E$ obtained for limestones, agglomerates, dolomites, chalks, sandstones, and basalts (Vásárhelyi 2005; Palchik 2007; Ocak 2008; Vásárhelyi and Davarpanah 2018; Asszonyi et al. 2016), among the others.

Hypothetical stress-strain curves for three different types of rock are presented in Fig. 1. by Ramamurthy et al. (2017). Based on the figure, curves OA, OB and OC represent three stress-strain curves with failure occurring at $\mathrm{A}, \mathrm{B}$ and $\mathrm{C}$, respectively. According to their sample, curves $\mathrm{OA}$ and $\mathrm{OB}$ have the same modulus but different strengths and strains at failure, whereas the curves OA and OC have the same strength but different modulus and strains at failure. It means, neither strength nor modulus alone could be chosen to represent the overall quality of rock. Therefore, strength and modulus together will give a realistic understanding of the rock response to engineering usage. This approaching of defining the quality of intact rocks was proposed by Deere and Miller (1966) considering the modulus ratio $\left(\mathrm{M}_{\mathrm{R}}\right)$, which is defined as the ratio of tangent modulus of intact rock $(E)$ at $50 \%$ of failure strength to its compressive strength $\left(\sigma_{\mathrm{c}}\right)$.

The modulus ratio $\left(\mathrm{M}_{\mathrm{R}}=\mathrm{E} / \sigma_{\mathrm{c}}\right)$ between the modulus of elasticity (E) and uniaxial compressive strength $\left(\sigma_{\mathrm{c}}\right)$ for intact rock samples varies from 106 to 1600 (Palmström and Singh 2001). For most rocks $M_{R}$ is between 250 and 500 with average $M_{R}=400$, $\mathrm{E}=400 \sigma_{\mathrm{c}}$.

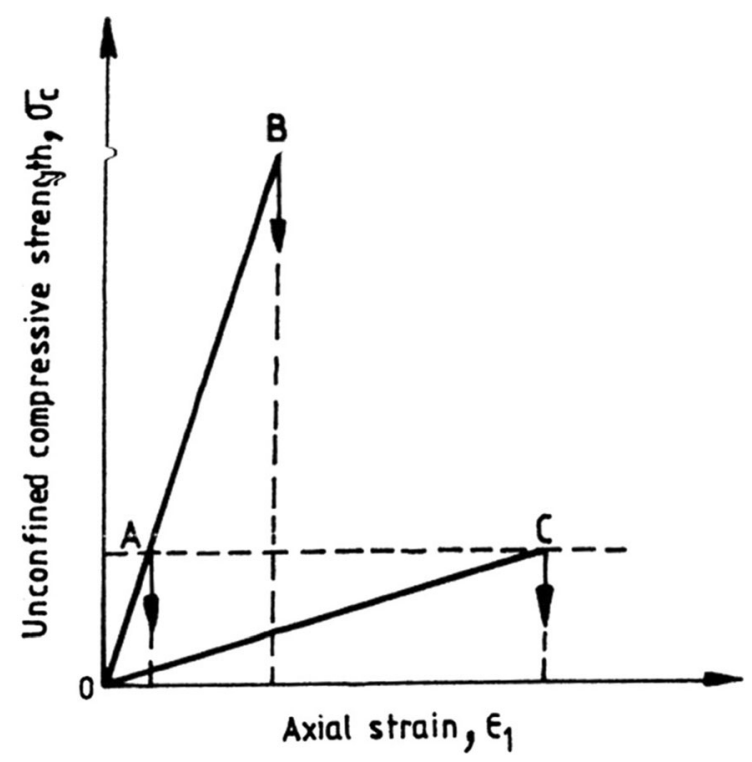

Fig. 1 Hypothetical stress-strain curves (Ramamurthy et al. 2017)
Palchik (2011) examined the $M_{R}$ values for 11 heterogeneous carbonate rocks from different regions of Israel. The investigated dolomites, limestones and chalks had weak to very strong strength with wide range of elastic modulus. He found that $\mathrm{M}_{R}$ is closely related to the maximum axial strain $\left(\varepsilon_{\mathrm{a}, \mathrm{max}}\right)$ at the uniaxial strength of the rock $\left(\sigma_{\mathrm{c}}\right)$ and the following relationship was found (see Fig. 2):

$M R=\frac{2 k}{\varepsilon_{a, \max }\left(1+e^{-\varepsilon_{a, \max }}\right)}$

where $\mathrm{k}$ is a conversion coefficient equal to 100 , and $\varepsilon_{\mathrm{a}, \max }$ is in $\%$. When $\mathrm{M}_{\mathrm{R}}$ is known, $\varepsilon_{\mathrm{a}, \max }(\%)$ is obtained from Eq. (1) as:

$\varepsilon_{a, \max }=\frac{k}{M R-0.46 k}$

Since the expansion of the expression 2/ $\left(1+e^{\varepsilon_{a \text { max }}}\right)$ using Taylor's theorem shows the value of $2 /\left(1+e^{\varepsilon_{a \text { max }}}\right)=1+0.46 \varepsilon_{\mathrm{a} \text {,max }}$ (Palchik 2013).

The goal of this paper is to check Eq. (1) for Hungarian granitic rock samples and study relations between characteristic compressive stress level, strain and mechanical properties, as well. Additionally, the validity of recently proposed mathematical model by Palchik (2019) for granitic rock samples was investigated. These granitic rock samples were investigated previously by Vásárhelyi et al. (2013) using multiple failure state triaxial tests (Figs. 3, 4).

\section{Laboratory Investigations and Analysing}

Laboratory samples originated from research boreholes deepened in carboniferous Mórágy Granite Formation during the research and construction phases of deep geological repository of low and intermediate level radioactive waste. This granite formation is a carboniferous intruded and displaced Variscan granite pluton situated in South-West Hungary. The main rock types are mainly microcline megacryst-bearing, medium-grained, biotite-monzogranites, and quartz monzonites (Buda 1985). In spatial viewpoint the monzogranitic rocks contain generally ovalshaped, variably elongated monzonite enclaves (predominantly amphibole-biotite monzonites, diorites, and syenites) of various size (from a few $\mathrm{cm}$ to several hundred metres) reflecting the mixing and mingling of two magmas with different composition. Feldspar- 


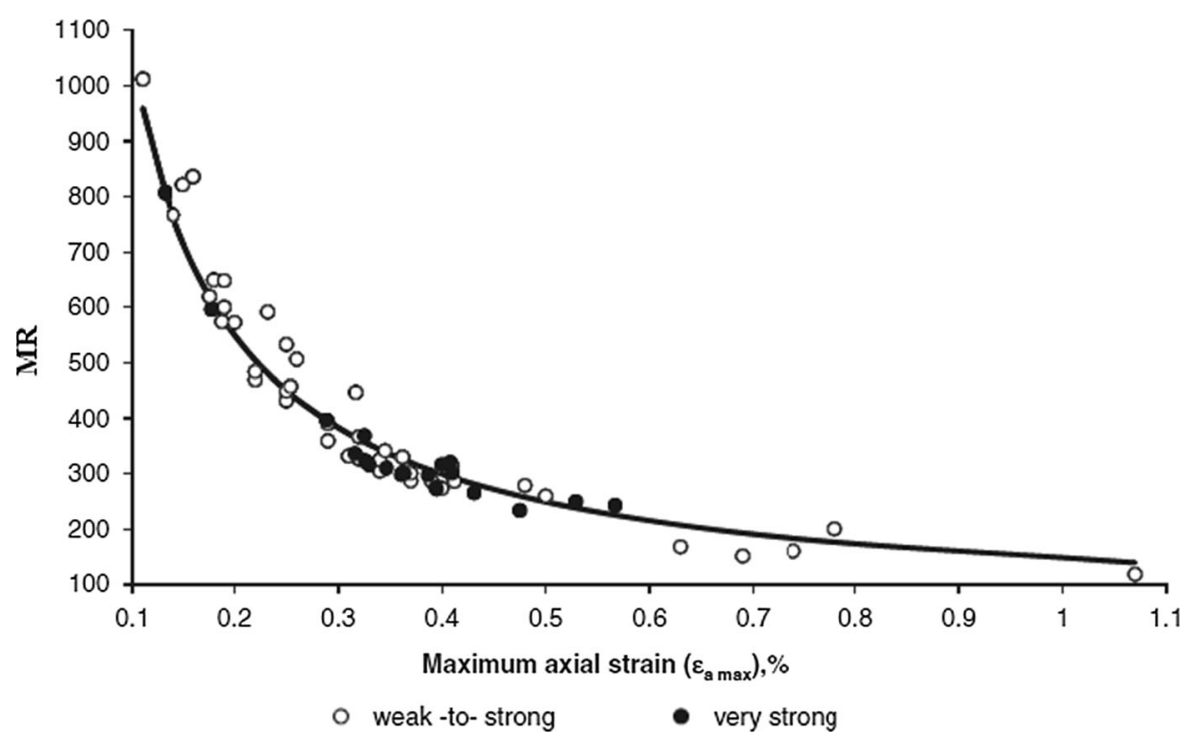

Fig. 2 Relationship between modulus ratio $\left(M_{R}\right)$ and maximum axial strain $\left(\varepsilon_{a, \text { max }}\right)$ using different carbonate rocks (Palchik 2011)

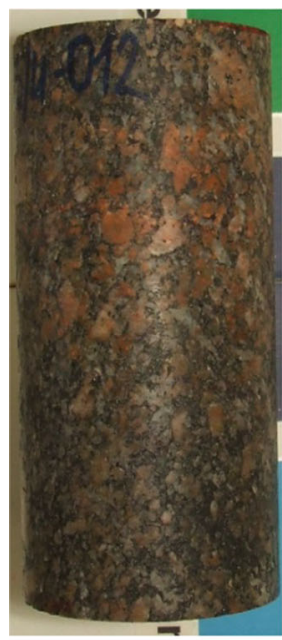

(a)

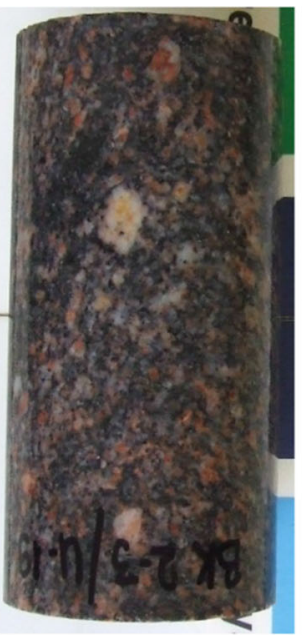

(b)

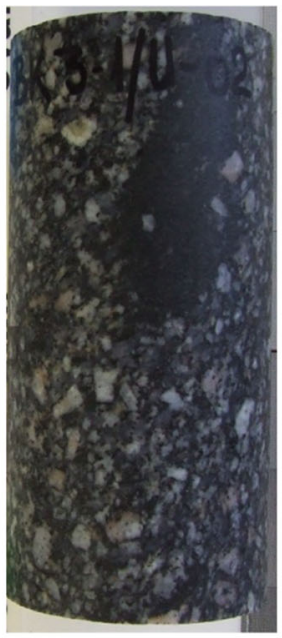

(c)

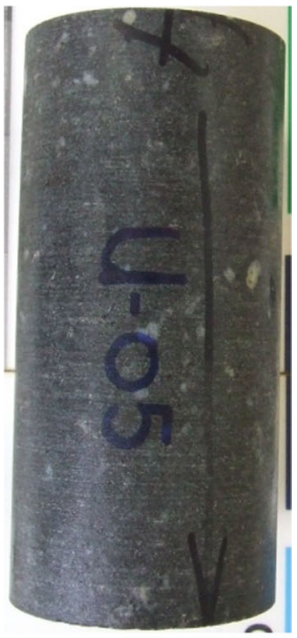

(d)

Fig. 3 Main types of rock samples. a, b megacryst-bearing, medium-grained, biotite-monzogranites, c medium-grained, biotitemonzogranites with elongated monzonitic enclaves, $\mathbf{d}$ quartz monzonite

quartz rich leucocratic dykes belonging to the latestage magmatic evolution and Late Cretaceous trachyte and tephryte dykes crosscut all of the previously described rock types (Király and Koroknai 2004). In general fractured but fresh rock is the common which is sparsely intersected by fault zones with few meter thick clay gauges. Intense clay mineralization in the fault cores indicates a low-grade hydrothermal alteration.
The samples were tested by using a computer controlled servo-hydraulic machine in continuous load control mode. The magnitude of loading was settled in $\mathrm{kN}$ with 0.01 accuracy, rate of loading was $0.6 \mathrm{kN} / \mathrm{s}$. Axial and tangential deformation were measured by strain gauges, that measures the deformation between $1 / 4$ and $3 / 4$ of the sample's height.

Fifty uniaxial compressive tests were performed in the rock mechanics laboratory at RockStudy Ltd. The $\mathrm{D}=50 \mathrm{~mm}$ sized cylindrical rock samples having the 


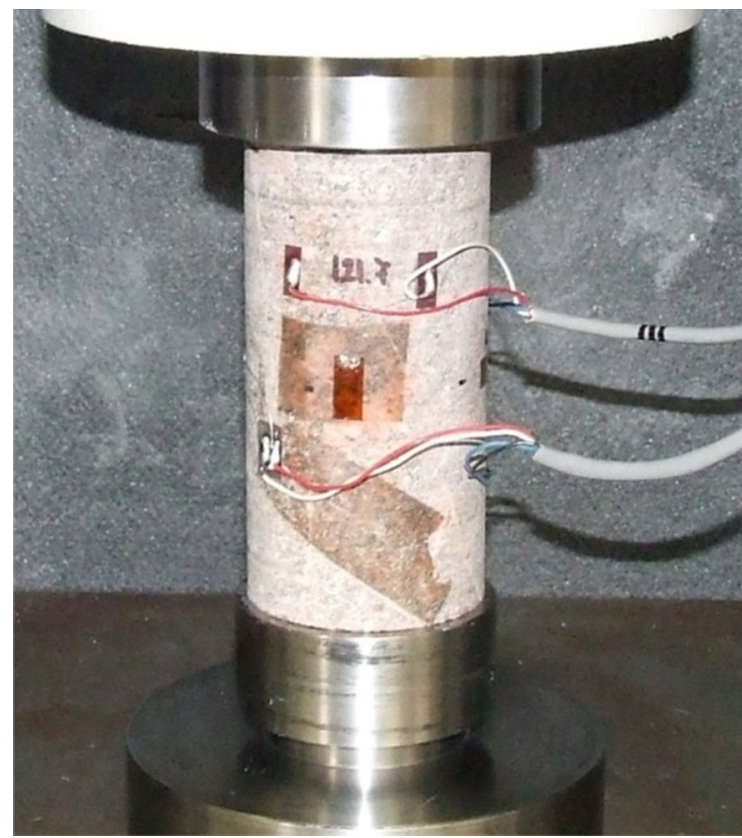

Fig. 4 A prepared sample in the beginning of the UCS test

ratio $\mathrm{L} / \mathrm{D}=2 / 1$ (here $\mathrm{L}$ and $\mathrm{D}$ is the length and diameter of a sample, respectively) were prepared. Mechanical properties of granitic rock samples are summarized in Table 1.

Table 1 shows the value of Modulus of elasticity $(E)$, Modulus of rigidity $(G)$ and Bulk modulus $(K)$, uniaxial compressive strength $\left(\sigma_{\mathrm{c}}\right)$, Poisson's ratio $(v)$, Axial failure strain $\left(\varepsilon_{a \operatorname{axax}}\right)$, and $\mathrm{M}_{\mathrm{R}}$ for each of the studied granitic samples.

The values of Tangent Young's modulus $\left(E_{\text {tan }}\right)$ is defined as the slope of a line tangent to the stressstrain curve at a fixed percentage $(50 \%)$ of the ultimate strength, the value of Average Young's modulus $(E)$ is defined as the slope of the straight-line part of the stress-strain curve, the value of Secant Young's modulus $\left(E_{s e c}\right)$ is defined as as the slope of the line from the origin (usually point $(0 ; 0)$ ) to some fixed percentage of ultimate strength, usually $50 \%$ and Poisson's ratio $(v)$ were calculated by using linear regressions along linear portions of stress-axial strain curves and radial strain-axial strain curves, respectively The International Society for Rock Mechanics suggests three standard methods for its determination (Ulusay and Hudson 2007). The value of $G_{t a n}, G_{s e c}$ and $K_{t a n}, K_{s e c}$ are calculated based on the following equations.

$$
\begin{aligned}
G_{\text {tan }, \mathrm{sec}} & =\frac{E_{\text {tan }, \mathrm{sec}}}{2\left(1+\vartheta_{\text {tan }, \mathrm{sec}}\right)} \\
K_{\text {tan }, \mathrm{sec}} & =\frac{E_{\text {tan }, \mathrm{sec}}}{3\left(1-2 \vartheta_{\text {tan }, \mathrm{sec}}\right)}
\end{aligned}
$$

The values of crack initiation stress $\left(\sigma_{\mathrm{ci}}\right)$ and crack damage stress $\left(\sigma_{\mathrm{cd}}\right)$ were calculated based on the following methods:

\subsection{Onset Dilatancy Method}

Brace et al. (1966) illustrated that crack initiation threshold is visible on the axial-volumetric strain curve when it diverges from the straight line (Fig. 5). In practice small deviation of the stress-volumetric strain curve from the straight line can make some difficulties to define one point determining the threshold of crack initiation.

\subsection{Crack Volumetric Strain Method}

Martin and Chandler (1994) proposed that crack initiation could be determined using a plot of crack volumetric strain versus axial strain (Fig. 6). Crack volumetric strain $\varepsilon_{\mathrm{Vcr}}$ is calculated as a difference of the elastic volumetric strain $\varepsilon_{\mathrm{Vel}}$ and volumetric strain $\varepsilon_{\mathrm{V}}$ determined in the test,

$\varepsilon_{\mathrm{V}}=\varepsilon_{1}+2 \varepsilon_{1},(\%)$

$\varepsilon_{V c r}=\varepsilon_{V}-\varepsilon_{V e l},(\%)$

$\varepsilon_{\text {Vel }}=\frac{1-2 v}{E}\left(\sigma_{1}+2 \sigma_{3}\right),(\%)$

$\varepsilon_{\mathrm{a}}, \varepsilon_{1}$ : axial and lateral strain, (\%)

$\sigma_{1}, \sigma_{3}$ : axial and confining stress, (MPa)

$\mathrm{E}, \mathrm{v}$; Young's modulus and Poisson's ratio, respectively, (GPa), (-)

Crack volumetric strain is calculated on the basis of these two elastic constants and is strongly sensitive to its value. This is probably why this method does not give objective values.

\subsection{Change of Poisson's Ratio Method}

Diederichs (2007) proposed a method of crack initiation threshold identification based on change of Poisson's ratio. The onset of crack initiation can be 
Table 1 Mechanical properties of investigated Mórágy granitic rock samples

\begin{tabular}{|c|c|c|c|c|c|c|c|c|c|c|c|c|}
\hline Rock sample & $\begin{array}{l}\vartheta_{\tan } \\
(-)\end{array}$ & $\begin{array}{l}\vartheta_{s e c} \\
(-)\end{array}$ & $\begin{array}{l}E_{\text {tan }} \\
(\mathrm{GPa})\end{array}$ & $\begin{array}{l}E_{s e c} \\
(\mathrm{GPa})\end{array}$ & $\begin{array}{l}G_{t a n} \\
(\mathrm{GPa})\end{array}$ & $\begin{array}{l}G_{s e c} \\
(\mathrm{GPa})\end{array}$ & $\begin{array}{l}K_{\tan } \\
(\mathrm{GPa})\end{array}$ & $\begin{array}{l}K_{s e c} \\
(\mathrm{GPa})\end{array}$ & $\begin{array}{l}\varepsilon_{\mathrm{a} \max } \\
(\%)\end{array}$ & $\begin{array}{l}\sigma_{\mathrm{c}} \\
(\mathrm{MPa})\end{array}$ & $\begin{array}{l}\mathrm{M}_{\mathrm{R}(\tan )} \\
(-)\end{array}$ & $\begin{array}{l}M_{R(\mathrm{sec})} \\
(-)\end{array}$ \\
\hline 1 & 0.3 & 0.24 & 56.52 & 74.39 & 36.74 & 46.12 & 7.54 & 12.89 & 0.278 & 181.05 & 312.20 & 410.89 \\
\hline 2 & 0.29 & 0.24 & 53.27 & 70.40 & 34.36 & 43.65 & 7.46 & 12.20 & 0.34 & 174.80 & 304.75 & 402.77 \\
\hline 3 & 0.32 & 0.28 & 56.55 & 73.91 & 37.32 & 47.30 & 6.79 & 10.84 & 0.33 & 183.39 & 308.37 & 403.03 \\
\hline 4 & 0.29 & 0.2 & 46.51 & 62.96 & 30.00 & 37.78 & 6.51 & 12.59 & 0.29 & 184.48 & 252.11 & 341.30 \\
\hline 5 & 0.3 & 0.25 & 46.93 & 63.96 & 30.51 & 39.98 & 6.26 & 10.66 & 0.22 & 137.14 & 342.22 & 466.41 \\
\hline 6 & 0.26 & 0.23 & 54.87 & 72.33 & 34.57 & 44.48 & 8.78 & 13.02 & 0.2 & 148.39 & 369.74 & 487.43 \\
\hline 7 & 0.28 & 0.24 & 46.07 & 62.83 & 29.48 & 38.96 & 6.76 & 10.89 & 0.27 & 156.74 & 293.92 & 400.86 \\
\hline 8 & 0.31 & 0.24 & 55.58 & 73.41 & 36.40 & 45.52 & 7.04 & 12.73 & 0.31 & 204.23 & 272.13 & 359.47 \\
\hline 9 & 0.23 & 0.2 & 58.56 & 76.42 & 36.02 & 45.85 & 10.54 & 15.28 & 0.18 & 133.34 & 439.21 & 573.09 \\
\hline 10 & 0.31 & 0.25 & 52.73 & 70.33 & 34.54 & 43.96 & 6.68 & 11.72 & 0.23 & 172.74 & 305.26 & 407.15 \\
\hline 11 & 0.3 & 0.23 & 54.24 & 72.05 & 35.26 & 44.31 & 7.23 & 12.97 & 0.28 & 184.59 & 293.86 & 390.33 \\
\hline 12 & 0.23 & 0.19 & 51.97 & 68.83 & 31.96 & 40.95 & 9.36 & 14.22 & 0.22 & 133.62 & 388.97 & 515.09 \\
\hline 13 & 0.24 & 0.18 & 53.39 & 69.90 & 33.10 & 41.24 & 9.25 & 14.91 & 0.18 & 153.60 & 347.59 & 455.07 \\
\hline 14 & 0.3 & 0.24 & 52.26 & 68.79 & 33.97 & 42.65 & 6.97 & 11.92 & 0.22 & 172.55 & 302.85 & 398.69 \\
\hline 15 & 0.26 & 0.21 & 41.58 & 57.60 & 26.20 & 34.85 & 6.65 & 11.14 & 0.27 & 135.14 & 307.68 & 426.23 \\
\hline 16 & 0.25 & 0.22 & 55.20 & 73.09 & 34.50 & 44.58 & 9.20 & 13.64 & 0.19 & 146.65 & 376.40 & 498.37 \\
\hline 17 & 0.28 & 0.26 & 58.87 & 77.57 & 37.68 & 48.87 & 8.63 & 12.41 & 0.19 & 143.71 & 409.66 & 539.79 \\
\hline 18 & 0.27 & 0.22 & 59.81 & 78.38 & 37.98 & 47.81 & 9.17 & 14.63 & 0.24 & 178.41 & 335.23 & 439.31 \\
\hline 19 & 0.26 & 0.21 & 55.15 & 73.22 & 34.74 & 44.30 & 8.82 & 14.16 & 0.23 & 159.16 & 346.50 & 460.05 \\
\hline 20 & 0.3 & 0.23 & 58.95 & 77.51 & 38.32 & 47.67 & 7.86 & 13.95 & 0.26 & 205.62 & 286.68 & 376.94 \\
\hline 21 & 0.25 & 0.21 & 57.81 & 76.08 & 36.13 & 46.03 & 9.63 & 14.71 & 0.20 & 155.49 & 371.78 & 489.28 \\
\hline 22 & 0.3 & 0.26 & 58.34 & 75.84 & 37.92 & 47.78 & 7.78 & 12.13 & 0.23 & 166.29 & 350.85 & 456.07 \\
\hline 23 & 0.28 & 0.25 & 58.56 & 76.25 & 37.48 & 47.66 & 8.59 & 12.71 & 0.30 & 161.63 & 362.32 & 471.77 \\
\hline 24 & 0.3 & 0.23 & 46.29 & 62.50 & 30.09 & 38.44 & 6.17 & 11.25 & 0.39 & 180.93 & 255.84 & 345.43 \\
\hline 25 & 0.28 & 0.23 & 59.62 & 78.12 & 38.16 & 48.04 & 8.74 & 14.06 & 0.24 & 179.28 & 332.57 & 435.75 \\
\hline 26 & 0.3 & 0.26 & 59.56 & 77.24 & 38.71 & 48.66 & 7.94 & 12.36 & 0.20 & 169.67 & 351.03 & 455.24 \\
\hline 27 & 0.27 & 0.22 & 56.89 & 73.94 & 36.13 & 45.10 & 8.72 & 13.80 & 0.20 & 164.59 & 345.67 & 449.25 \\
\hline 28 & 0.31 & 0.26 & 58.41 & 76.71 & 38.26 & 48.33 & 7.40 & 12.27 & 0.24 & 187.69 & 311.18 & 408.71 \\
\hline 29 & 0.28 & 0.22 & 52.50 & 70.11 & 33.60 & 42.77 & 7.70 & 13.09 & 0.36 & 184.45 & 284.63 & 380.09 \\
\hline 30 & 0.29 & 0.25 & 57.79 & 76.13 & 37.27 & 47.58 & 8.09 & 12.69 & 0.28 & 170.10 & 339.71 & 447.54 \\
\hline 31 & 0.28 & 0.24 & 60.69 & 79.25 & 38.84 & 49.14 & 8.90 & 13.74 & 0.25 & 177.91 & 341.13 & 445.46 \\
\hline 32 & 0.31 & 0.26 & 56.42 & 74.42 & 36.96 & 46.88 & 7.15 & 11.91 & 0.26 & 181.43 & 310.98 & 410.18 \\
\hline 33 & 0.28 & 0.22 & 58.58 & 76.23 & 37.49 & 46.50 & 8.59 & 14.23 & 0.25 & 190.48 & 307.53 & 400.21 \\
\hline 34 & 0.29 & 0.25 & 56.17 & 74.22 & 36.23 & 46.39 & 7.86 & 12.37 & 0.24 & 165.23 & 339.96 & 449.18 \\
\hline 35 & 0.3 & 0.28 & 52.51 & 73.50 & 34.13 & 47.04 & 7.00 & 10.78 & 0.23 & 149.76 & 350.65 & 490.79 \\
\hline 36 & 0.31 & 0.28 & 58.18 & 76.84 & 38.11 & 49.18 & 7.37 & 11.27 & 0.26 & 171.46 & 339.32 & 448.15 \\
\hline 37 & 0.27 & 0.22 & 48.53 & 65.28 & 30.82 & 39.82 & 7.44 & 12.19 & 0.29 & 149.28 & 325.11 & 437.29 \\
\hline 38 & 0.3 & 0.26 & 58.17 & 81.37 & 37.81 & 51.27 & 7.76 & 13.02 & 0.27 & 180.33 & 322.58 & 451.25 \\
\hline 39 & 0.32 & 0.3 & 64.47 & 83.74 & 42.55 & 54.43 & 7.74 & 11.16 & 0.2 & 166.87 & 386.36 & 501.80 \\
\hline 40 & 0.31 & 0.29 & 60.28 & 79.54 & 39.48 & 51.30 & 7.64 & 11.14 & 0.26 & 169.70 & 355.21 & 468.71 \\
\hline 41 & 0.32 & 0.26 & 58.70 & 77.53 & 38.74 & 48.84 & 7.04 & 12.40 & 0.37 & 212.42 & 276.34 & 364.99 \\
\hline 42 & 0.29 & 0.25 & 62.81 & 71.85 & 40.51 & 44.91 & 8.79 & 11.98 & 0.23 & 178.07 & 352.70 & 403.50 \\
\hline 43 & 0.3 & 0.27 & 62.79 & 81.89 & 40.81 & 52.00 & 8.37 & 12.56 & 0.26 & 166.94 & 376.13 & 490.54 \\
\hline 44 & 0.28 & 0.26 & 59.91 & 78.42 & 38.35 & 49.41 & 8.79 & 12.55 & 0.19 & 142.49 & 420.48 & 550.38 \\
\hline
\end{tabular}


Table 1 continued

\begin{tabular}{lllllllllllll}
\hline Rock sample & $\begin{array}{l}\vartheta_{\text {tan }} \\
(-)\end{array}$ & $\begin{array}{l}\vartheta_{\text {sec }} \\
(-)\end{array}$ & $\begin{array}{l}E_{\text {tan }} \\
(\mathrm{GPa})\end{array}$ & $\begin{array}{l}E_{\text {sec }} \\
(\mathrm{GPa})\end{array}$ & $\begin{array}{l}G_{\text {tan }} \\
(\mathrm{GPa})\end{array}$ & $\begin{array}{l}G_{\text {sec }} \\
(\mathrm{GPa})\end{array}$ & $\begin{array}{l}K_{\text {tan }} \\
(\mathrm{GPa})\end{array}$ & $\begin{array}{l}K_{\text {sec }} \\
(\mathrm{GPa})\end{array}$ & $\begin{array}{l}\varepsilon_{\mathrm{a} \max } \\
(\%)\end{array}$ & $\begin{array}{l}\sigma_{\mathrm{c}} \\
(\mathrm{MPa})\end{array}$ & $\begin{array}{l}\mathrm{M}_{\mathrm{R}(\mathrm{tan})} \\
(-)\end{array}$ & $\begin{array}{l}\mathrm{M}_{\mathrm{R}(\mathrm{sec})} \\
(-)\end{array}$ \\
\hline 45 & 0.31 & 0.28 & 59.16 & 77.52 & 38.75 & 49.61 & 7.49 & 11.37 & 0.23 & 163.19 & 362.49 & 475.00 \\
46 & 0.29 & 0.21 & 54.44 & 71.56 & 35.12 & 43.29 & 7.62 & 13.84 & 0.3 & 192.80 & 282.38 & 371.17 \\
47 & 0.3 & 0.24 & 54.95 & 72.92 & 35.71 & 45.21 & 7.33 & 12.64 & 0.28 & 198.58 & 276.69 & 367.21 \\
48 & 0.3 & 0.22 & 53.30 & 70.57 & 34.64 & 43.05 & 7.11 & 13.17 & 0.29 & 213.04 & 250.17 & 331.25 \\
49 & 0.34 & 0.3 & 68.31 & 87.97 & 45.77 & 57.18 & 7.29 & 11.73 & 0.23 & 206.48 & 330.84 & 426.06 \\
50 & 0.31 & 0.27 & 50.05 & 67.02 & 32.78 & 42.56 & 6.34 & 10.28 & 0.28 & 159.97 & 312.89 & 418.96 \\
\hline
\end{tabular}

Fig. 5 Axial stressvolumetric strain curve with the threshold of crack initiation and crack damage and failure stress for Hungarian granitic samples (uniaxial compression case)

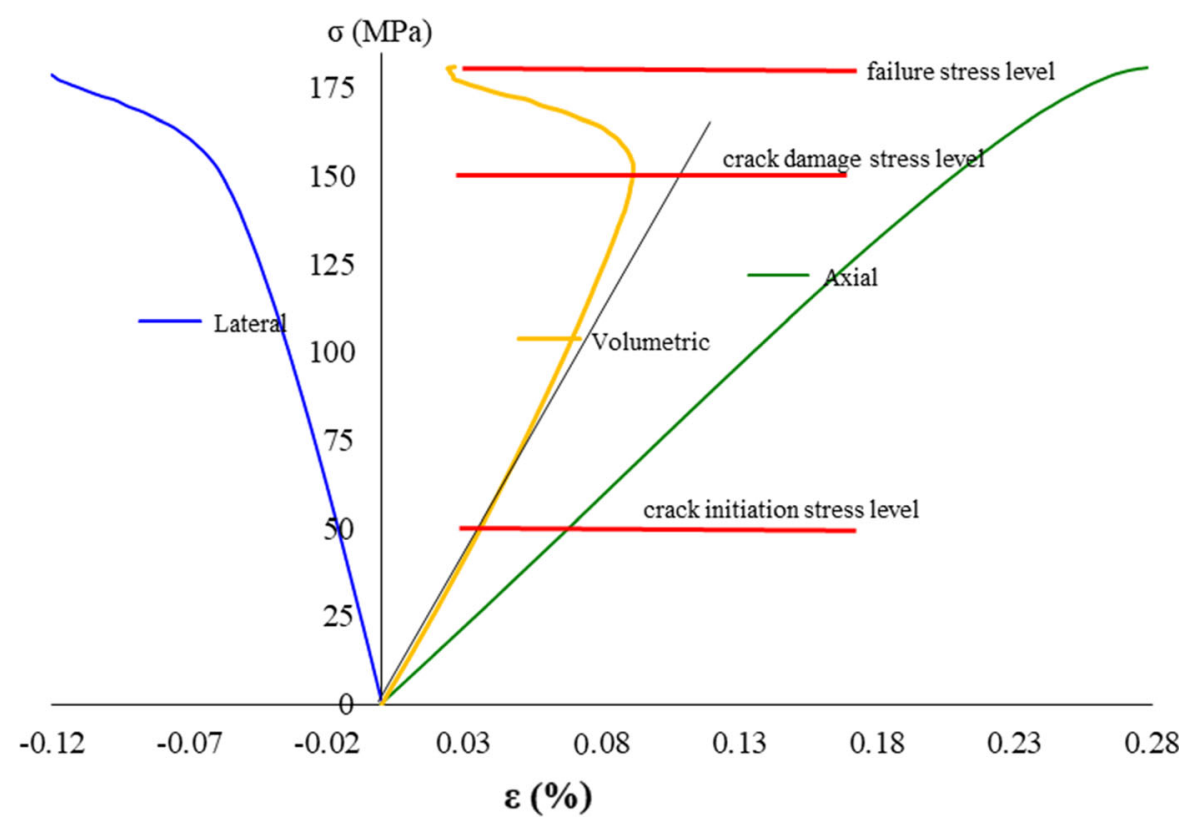

identified by analysis of the relation of Poisson's ratio, evaluated locally, to the log of the axial stress (Fig. 7).

However, in this paper, the results obtained from the first method were used for further analysis. The reason is that, based on the findings by Cieslik (2014), this method gives more precise results for granitic rock samples.

The value of $M_{R}$ in each of 50 studied granitic rock samples is between 326.4 and 597.4 with the mean of 439.4. The range of $M_{R}$ obtained by Deere (1968) is between 250 and 700 with the mean of 420 for limestone and dolomites. The range of $\mathrm{M}_{\mathrm{R}}$ obtained by Palchik (2011) is between 60.9 and 1011.4 with the mean value of 380.5 for carbonated rock samples. The mean value of $M_{R}$ in this study is similar to the mean value of $\mathrm{M}_{\mathrm{R}}$ obtained by Deere (1968) and Palchik (2011). Figure 8 shows the value of $M_{R}$ for all studied samples in this study. As it can be seen from Fig. 5, the range of $M_{R}=326.4-597.4$, observed in this study is narrower than the range of $\mathrm{M}_{\mathrm{R}}$ obtained by Deere (1968) and Palchik (2011).

The ranges of the elastic modulus (E), Poisson's ratio $(v)$, crack damage stress $\left(\sigma_{\mathrm{cd}}\right)$ and uniaxial compressive strength $\left(\sigma_{\mathrm{c}}\right)$, axial failure strain $\left(\varepsilon_{\mathrm{a} \max }\right)$ and maximum volumetric strain $\left(\varepsilon_{\mathrm{cd}}\right)$, crack initiation stress $\left(\sigma_{\mathrm{ci}}\right)$ and crack initiation strain $\left(\varepsilon_{\mathrm{ci}}\right)$ for the studied 50 samples are presented as following (Davarpanah et al. 2019). The histogram of measured parameters is exhibited in Fig. 9. 


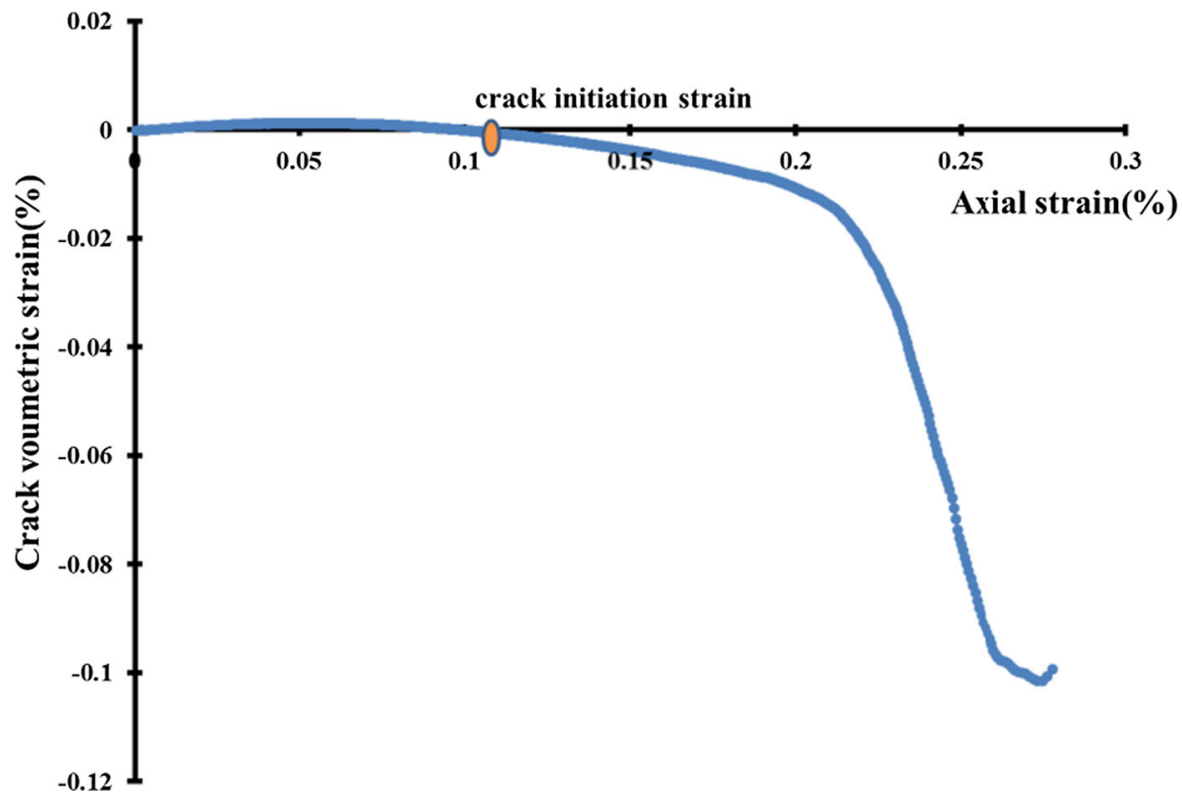

Fig. 6 Crack volumetric strain method for crack initiation threshold determination for Hungarian granitic rock sample (uniaxial compression case)

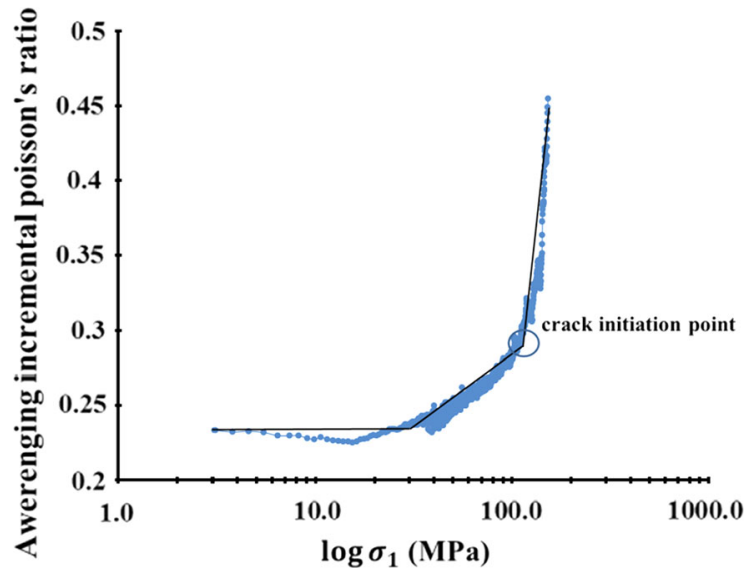

Fig. 7 Poisson's ratio method for crack initiation threshold determination for Hungarian granitic rock samples (uniaxial compression case)

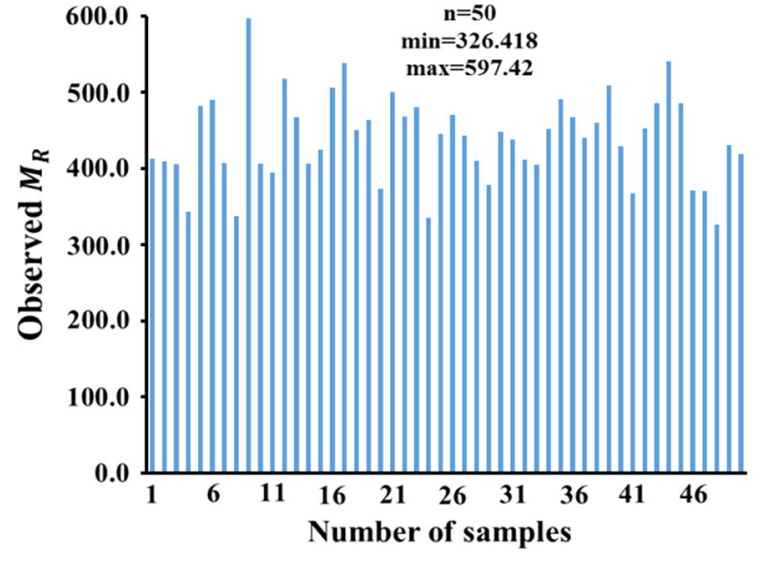

Fig. 8 Observed values of modulus ratio $\left(M_{R}\right)$ in each of 50 examined rock samples

\section{Relationship Between Mechanical Parameters and Deformation Constants}

The relationship between uniaxial compressive strength $\left(\sigma_{c}\right), M_{R}$ and $E$ is shown in Fig. 10.

As it is clear, the elastic modulus is related to $\left(\sigma_{\mathrm{c}}\right)$, (with $R^{2}=0.06$ very small). It also demonstrates that increase in the value of $\sigma_{\mathrm{c}}$ from 133 to $213 \mathrm{MPa}$ 

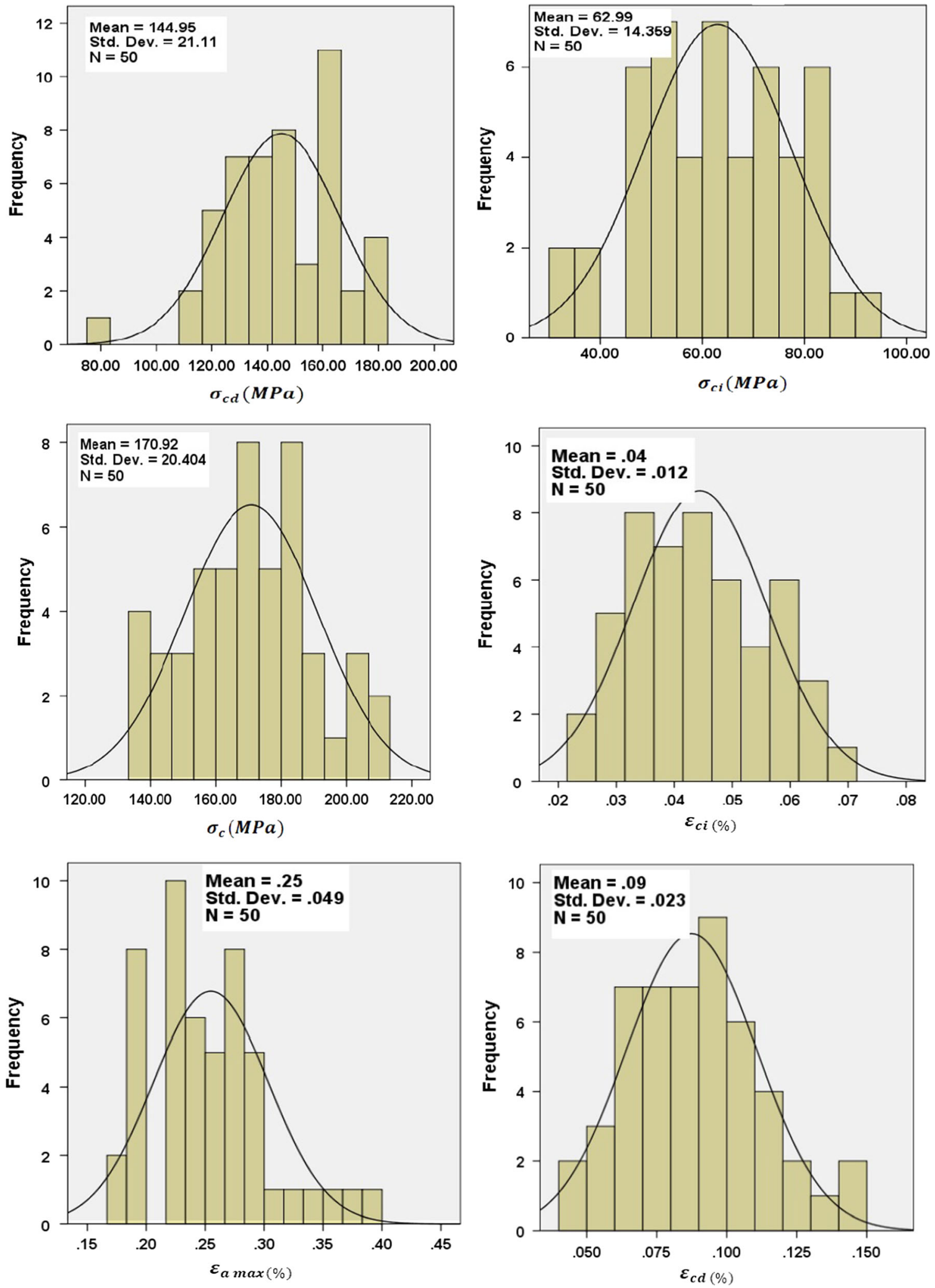

Fig. 9 Histogram of measured parameters 
doesn't influence E value. It can be seen from Fig. 10 that $\mathrm{M}_{\mathrm{R}}$ is related to $\left(\sigma_{\mathrm{c}}\right.$ ), (with $R^{2}=0.61$ ). These values, however, are different from the values found by Palchik (2011) for carbonated rocks. In his studies the elastic modulus is partly related to uniaxial compressive strength with $R^{2}=0.55$ and increase in the value of $\sigma_{c}$ doesn't influence $M_{R}$ value $\left(R^{2}=0.021\right.$ is very small).

The observed and analytical (Eq. 1) relationships between $\varepsilon_{\mathrm{a} \text { max }}$ and $\mathrm{M}_{\mathrm{R}}$ for all rock samples exhibiting $\varepsilon_{\mathrm{a} \max }<1 \%$ is plotted in Fig. 11. It is clear that the calculated (Eq. 1) and observed values of $M_{R}$ for studied rock samples are similar. Figure 12 presents relative and root-mean square errors between the calculated (Eq. 1) and observed $\mathrm{M}_{\mathrm{R}}$ at $\varepsilon_{\mathrm{a} \max }<1 \%$. As it is clear, the relative error $(\varsigma, \%)$ for studied samples is between 0.28 and $25 \%$ and root-mean square error is $(\chi=50)$. Compare the values with the results obtained by Palchik (2011) for carbonate rock samples, the relative error is between 0.08 and $10.8 \%$ and the root-mean square error is 43.6. The relative $(\varsigma, \%)$ and root-mean-square $(\chi)$ errors between the observed and calculated parameter $\Pi$ have been calculated as: $\varsigma_{(m)}=\frac{2\left|\prod_{\mathrm{obs}(j)}-\prod_{\mathrm{cal}(j)}\right|}{\prod_{\mathrm{obs}(j)}+\prod_{\mathrm{cal}(j)}} \times 100$

$\chi_{(m)}=\sqrt{\frac{\sum_{j=1}^{n}\left[\prod_{\mathrm{obs}(j)}-\prod_{\mathrm{cal}(j)}\right]^{2}}{n-1}}$

where $\Pi_{o b s(j)}$ is the observed value of parameter in jth sample, here is $M_{R}, \Pi_{c a l(j)}$ is the calculated value of parameter in $\mathrm{jth}$ sample, $\mathrm{j}=1,2, \ldots, \mathrm{n}$, is the number of tested samples, here is 50 .

\section{Relationship Between Deformation Constants $\left(\mathrm{E}, \mathrm{G}, \mathrm{K}, \mathrm{v}, \mathrm{M}_{\mathrm{R}}\right)$}

Correlation between Tangant Young's modulus $\left(E_{t a n}\right)$ and Secant Young's modulus, Tangant Modulus of rigidity $\left(G_{t a n}\right)$ and Secant Modulus of rigidity $\left(G_{s e c}\right)$, Tangant Bulk modulus $\left(K_{t a n}\right)$ and Secant Bulk Modulus $\left(K_{s e c}\right)$, Tangant Poisson's ratio $\left(\vartheta_{\text {tan }}\right)$ and Secant Poisson's ratio $\left(\vartheta_{\text {sec }}\right)$, Tangant Modulus ratio $\left(M_{\text {Rtan }}\right)$ and Secant Modulus ratio $\left(M_{\text {Rsec }}\right)$ were investigated (Fig. 13).

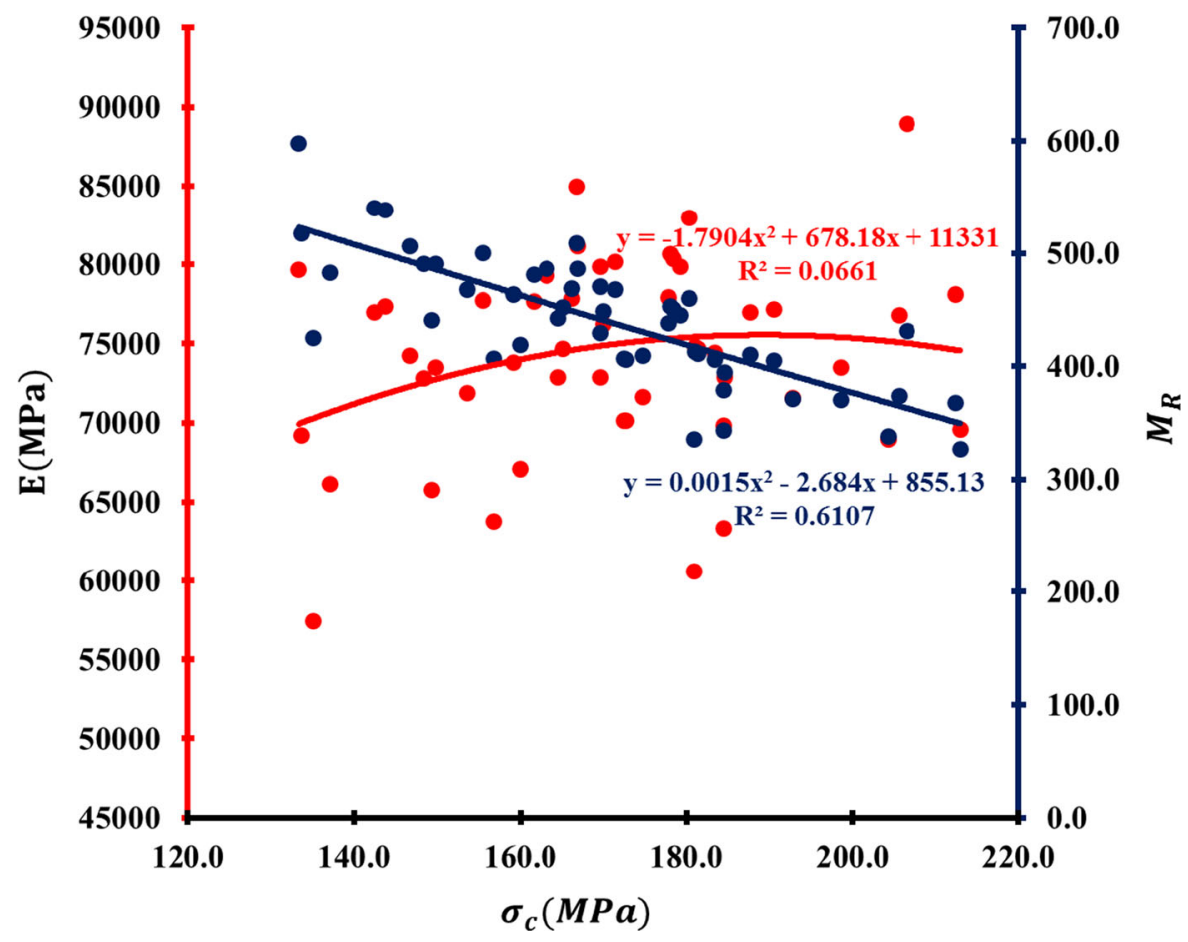

Fig. 10 The Influence of uniaxial compressive strength $\left(\sigma_{c}\right)$ on elastic modulus (E) and the value of $M_{R}$ for all studied samples 


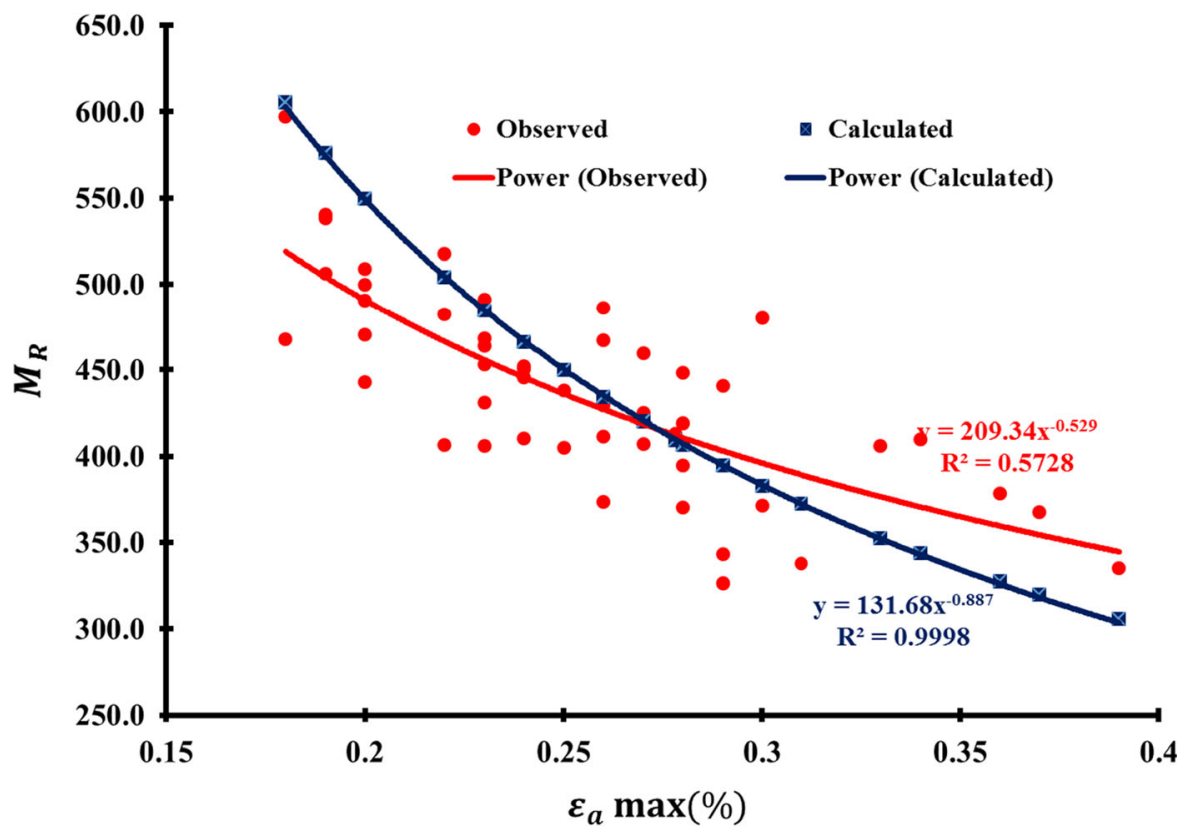

Fig. 11 The observed and analytical (Eq. 1) relationship between $\varepsilon_{\mathrm{a} \max }$ and $M_{R}$

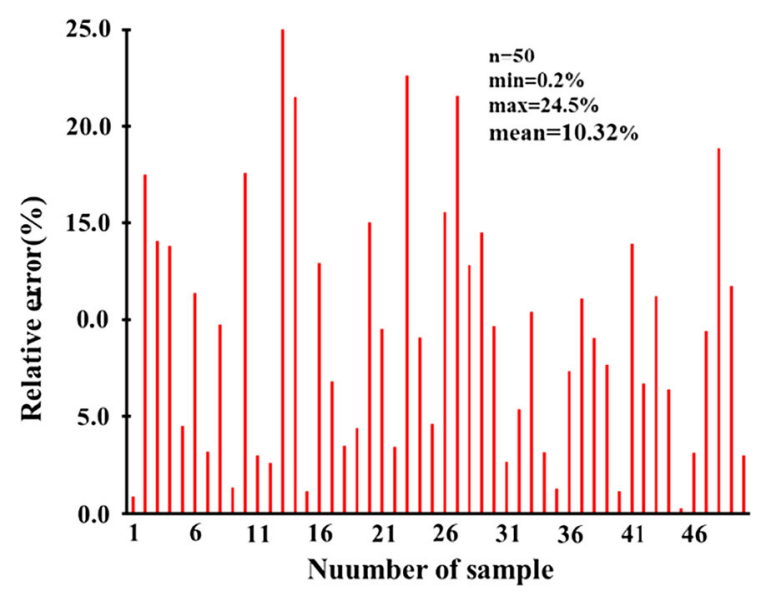

Fig. 12 Relative $(\varsigma, \%)$ and root-mean-square $(\chi)$ errors between calculated (Eq. 1) and observed $M_{R}$

According to Fig. 13a, we can see good linear correlation between tan and secant Young's modulus , tan and secant modulus of rigidity (Fig. 13b), tan and secant modulus ratio (Fig. 13e), tan Young's modulus and rigidity modulus (Fig. 13f), secant Young's modulus and rigidity modulus (Fig. 13g).

\section{Investigation of the Validity of Mathematical Model Proposed by Palchik (2019) for Granitic Rock Samples}

Palchik (2019) proposed a simple stress-strain model for very strong $\left(\sigma_{c}>100 \mathrm{MPa}\right)$ carbonate rocks based on Haldane's distribution function (Haldane 1919).

$\sigma_{a}=\sigma_{c}\left(\frac{1-e^{-s \varepsilon_{a}}}{1-e^{-\theta}}\right)$

where $\sigma_{a}$ is a current axial stress (MPa), $\varepsilon_{a}$ is a current axial strain (\%) at the axial stress $\sigma_{a}, \sigma_{c}$ is a uniaxial compressive strength (MPa), parameter (s) is a constant involved in a canonical form of Haldane's function. For very strong limestones and dolomites $\left(\sigma_{c}>100 \mathrm{MPa}\right)$ the value of $\mathrm{s}$ is between 0.5 and 1 , and exponent $\theta$ is defined as follows

$\theta=-\ln \left[1-\frac{\sigma_{c}}{\sigma_{a}}\left(1-e^{-0.5 \varepsilon_{a}}\right)\right]$

And can be presented in the following form by using Taylor's series expansion:

$\theta=\emptyset+\frac{\emptyset^{2}}{2}+\frac{\emptyset^{3}}{3}$ 

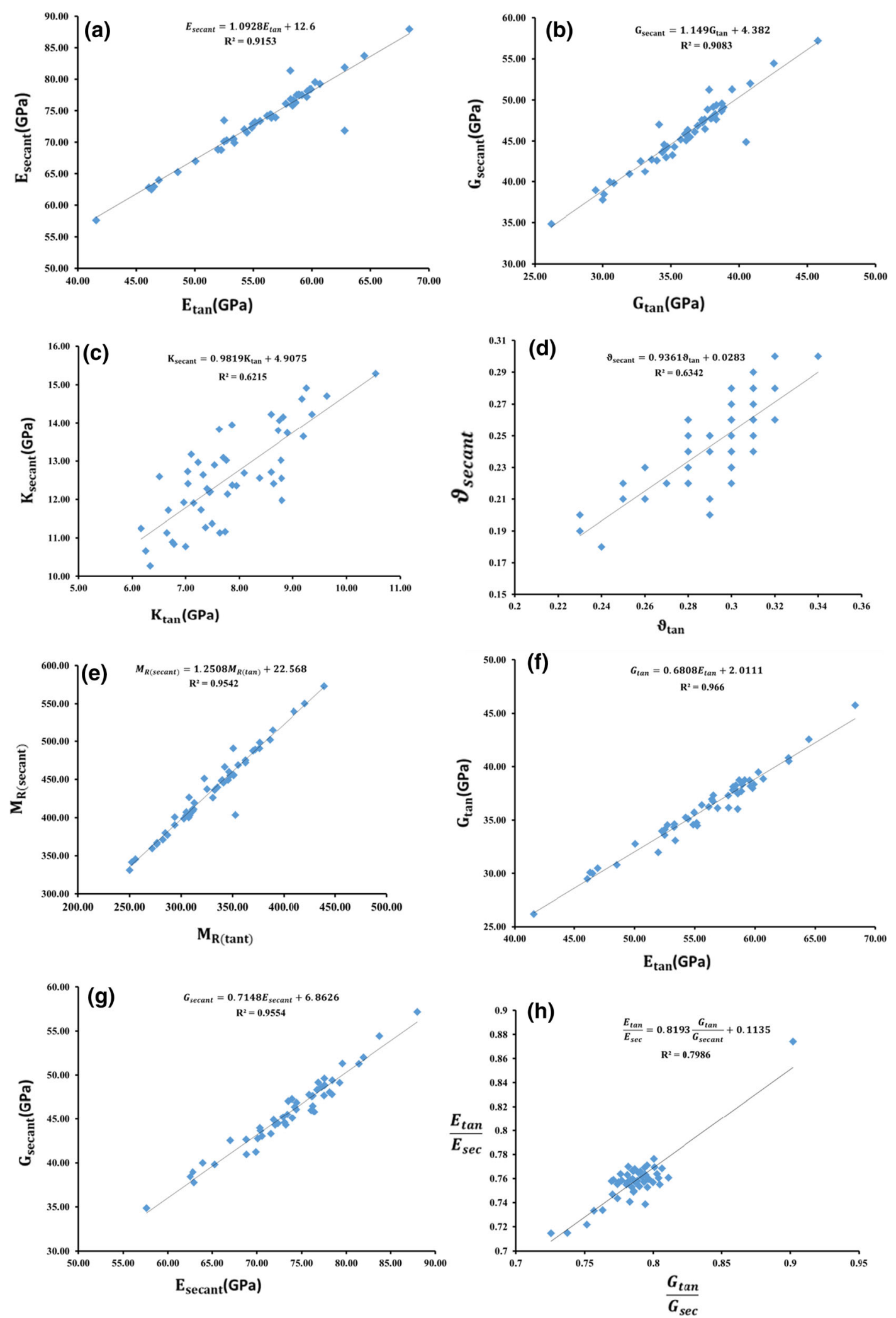

Fig. 13 Relationships between deformation constants $\left(\mathbf{E}, \mathbf{G}, \mathbf{K}, \mathbf{v}, \mathbf{M}_{\mathbf{R}}\right)$ 
$\emptyset=\left(\frac{\sigma_{c}}{\sigma_{a 1}}\right)\left(1-e^{-0.5 \varepsilon_{a 1}}\right)$

when $\mathrm{s}=1.1$ :

$\sigma_{a}=\sigma_{c}\left(\frac{1-e^{-1.1 \varepsilon_{a}}}{1-e^{-\psi}}\right)$

$\psi=-\ln \left[1-\frac{\sigma_{c}}{\sigma_{a}}\left(1-e^{-1.1 \varepsilon_{a}}\right)\right]$

$\psi=v+\frac{v^{2}}{2}+\frac{v^{3}}{3}$

$v=\left(\frac{\sigma_{c}}{\sigma_{a 1}}\right)\left(1-e^{-1.1 \varepsilon_{a 1}}\right)$
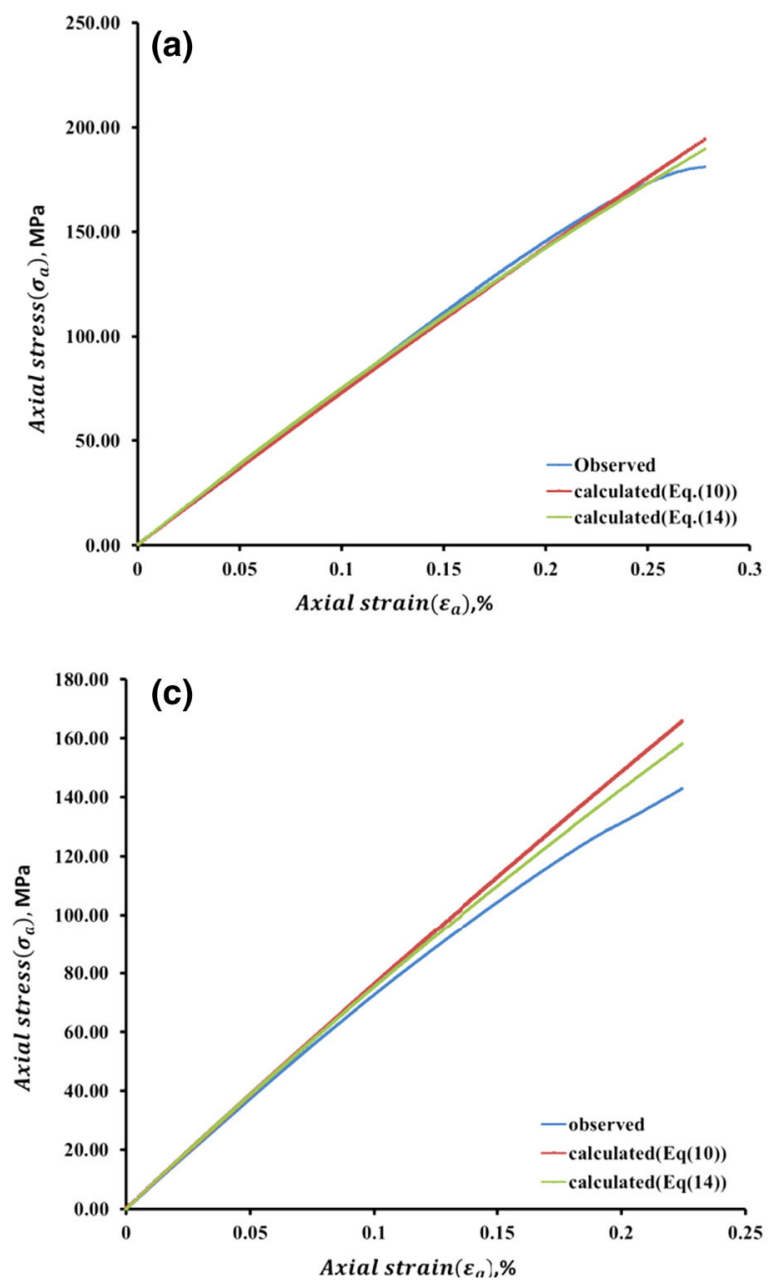

The estimated and observed stress-strain relationships for four granitic rock samples are presented in Fig. 14. The relevant modelling parameters used in Fig. 14. are followings:

Sample(a1): $\sigma_{c}=181.05 \mathrm{MPa}, \sigma_{a 1}=27.8 \mathrm{MPa}$ at $\varepsilon_{a 1}=0.037 \%$

Sample(b4): $\sigma_{c}=184.48 \mathrm{MPa}, \sigma_{a 1}=22.22 \mathrm{MPa}$ at $\varepsilon_{a 1}=0.042 \%$

Sample(c6): $\sigma_{c}=148.39 \mathrm{MPa}, \sigma_{a 1}=34.44 \mathrm{MPa}$ at $\varepsilon_{a 1}=0.045 \%$

Sample(d8): $\sigma_{c}=204.23 \mathrm{MPa}, \sigma_{a 1}=28.93 \mathrm{MPa}$ at $\varepsilon_{a 1}=0.032 \%$

According to our calculations, the proposed model by Palchik (2019) for very strong limestones and
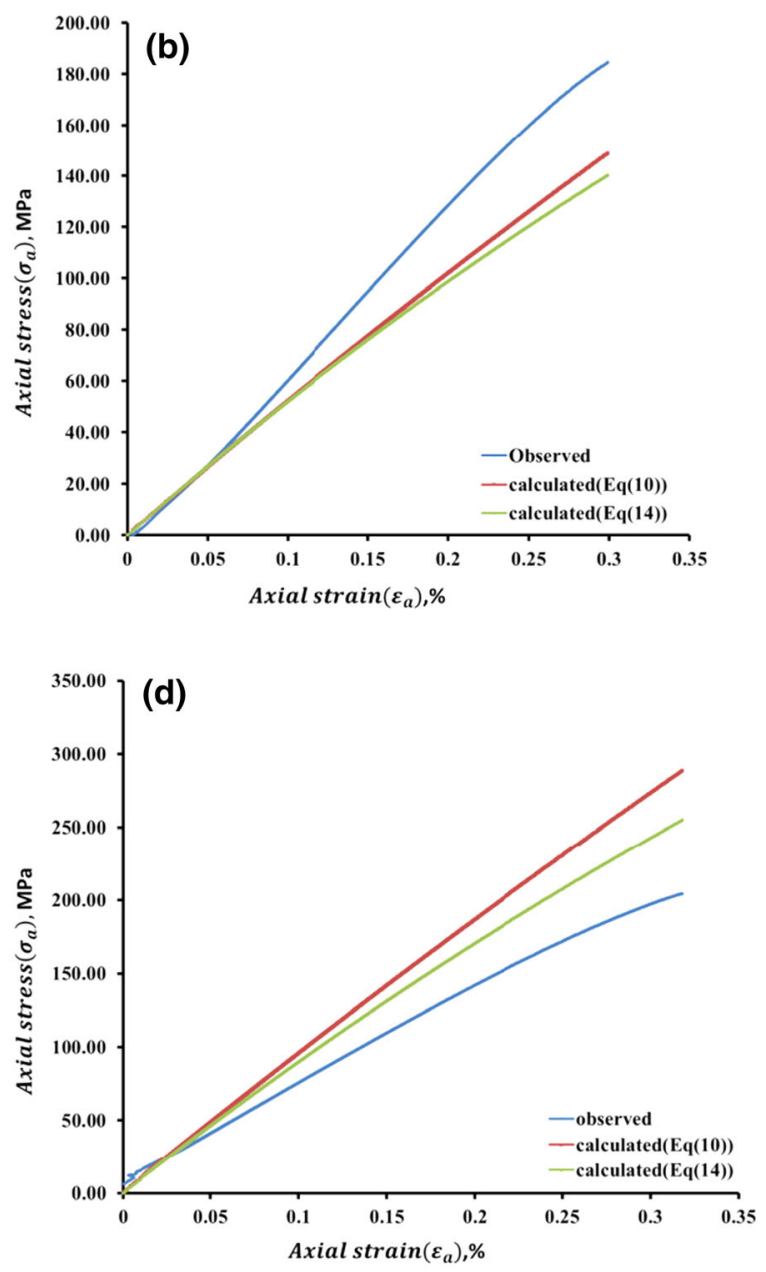

Fig. 14 Examples of comparison of stress-strain models [Eqs. (10), (14)] and stress-strain relationships observed in this study for very strong $\left(\sigma_{\mathrm{c}}>100 \mathrm{MPa}\right)$ granitic rock samples $(\mathbf{a}, \mathbf{b}, \mathbf{c}, \mathbf{d})$ 

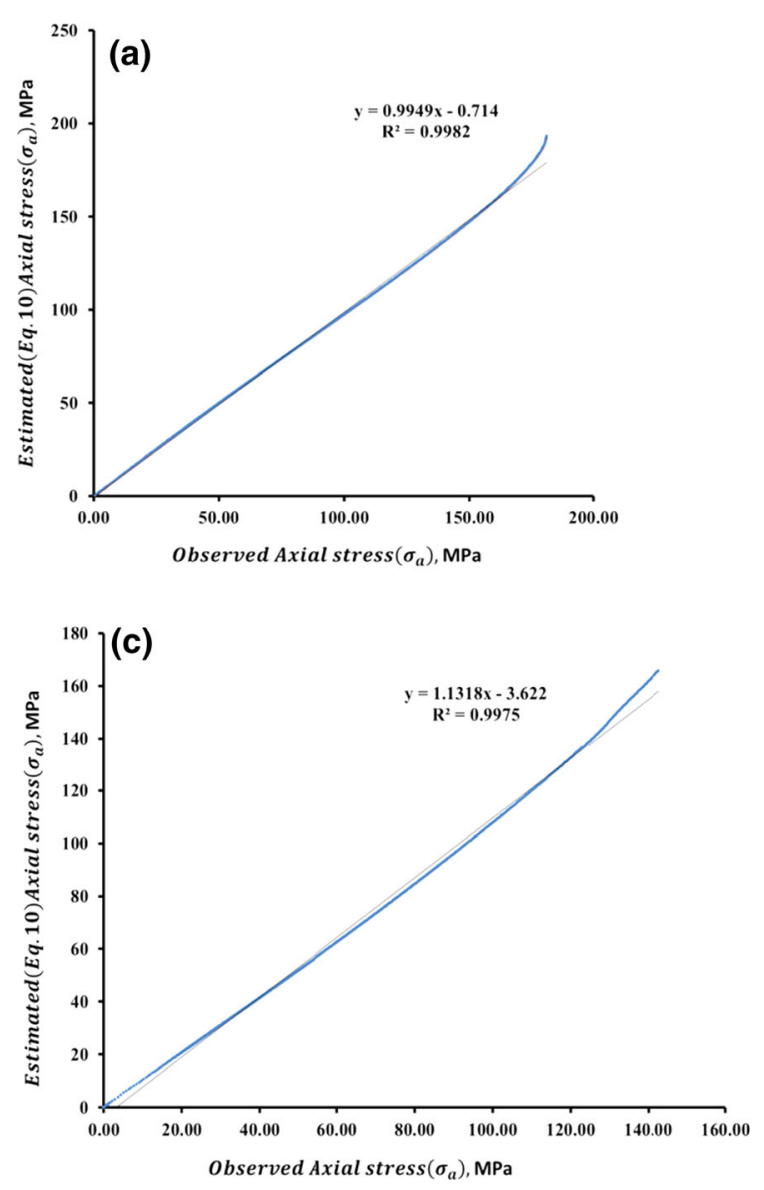
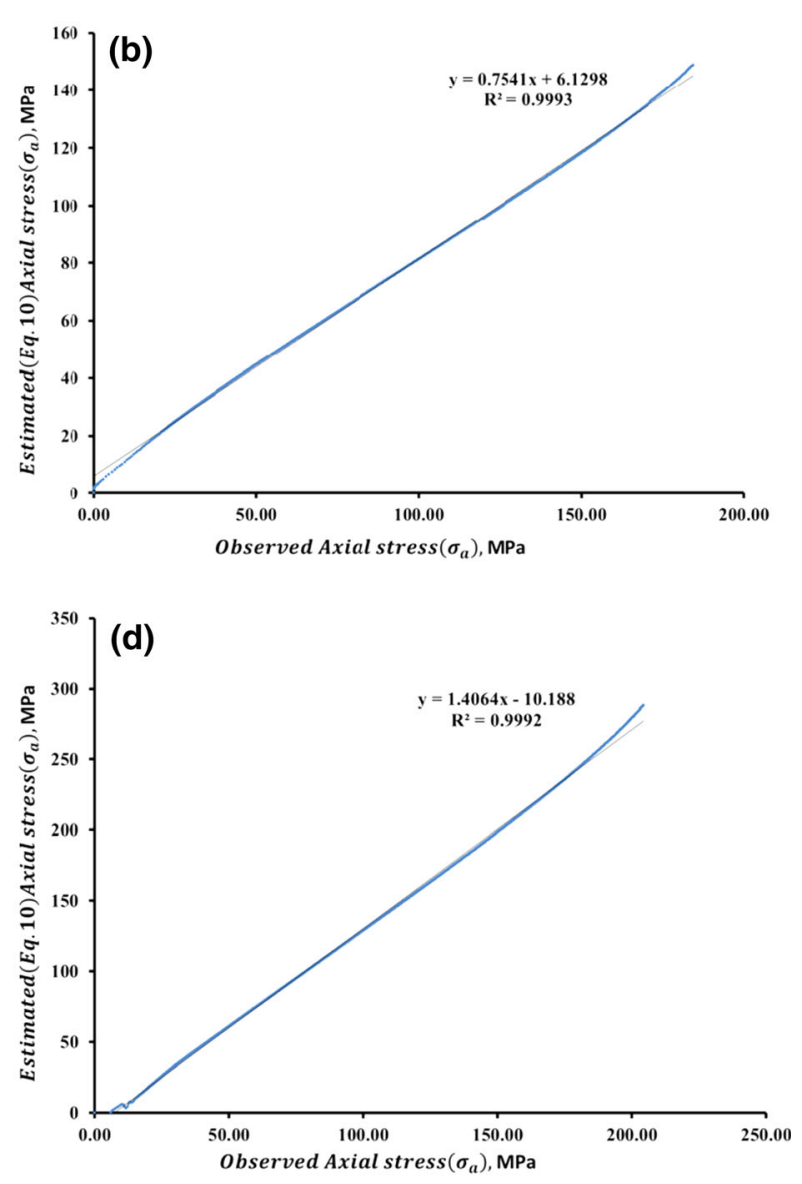

Fig. 15 Linear correlation between observed and estimated (Eq. 10) axial stresses for granitic rock samples

dolomites is in good agreement with the elastic region of stress-strain relationships observed in this study for very strong granitic rock samples. However, there is a significant difference in non-linear part of stress-strain relationships between the observed and estimated values.

Comparison between estimated [Eqs. (10) and (14)], and observed axial stresses for studied rock samples shows a very good linear correlation between these stresses, and thus, Eq. 10 can predict stresses well (Fig. 15).

\section{Discussion}

The laboratory compressive tests, statistical analysis, and empirical and analytical relations have been used to estimate the values of $\mathrm{M}_{\mathrm{R}}=\mathrm{E} / \sigma_{\mathrm{c}}$ and its relationship with other mechanical parameters for granitic rocks. Studied rock samples exhibiting the wide range of mechanical properties $(57.425 \mathrm{GPa}<$ $\mathrm{E}<88.937 \mathrm{GPa}, 0.18<\mathrm{v}<0.32,77.3 \mathrm{MPa}<\sigma_{\text {cd- }}$ $<212.42 \mathrm{MPa}, \quad 133.34 \mathrm{MPa}<\sigma_{\mathrm{c}}<213.04 \mathrm{MPa}$, $\left.0.18<\varepsilon_{\mathrm{a} \max }<0.19,0.04<\varepsilon_{\mathrm{cd}}<0.14\right)$. The ranges of $\frac{\varepsilon_{a \max }}{\varepsilon_{c d}}$ and $\frac{\sigma_{c d}}{\sigma_{c}}$ and $\frac{\sigma_{c i}}{\sigma_{c}}$ ratios are 1.49-5.28 and 0.5-0.9 and $0.2-0.5$, respectively. These values are different from the values of $\frac{\sigma_{c d}}{\sigma_{c}}=0.5-1.0$ and $\frac{\varepsilon_{a m a x}}{\varepsilon_{c d}}=1.51-6.91$ obtained by Palchik (2011). They are also different from the values of $\frac{\sigma_{c d}}{\sigma_{c}}=0.71-0.84$ obtained by Brace et al. (1966), Bieniawski (1967), Martin (1993), Pettitt et al. (1998), Eberhardt et al. (1999), Heo et al. (2001), Katz and Reches (2004) for granites, sandstones and quartzite. The range of $\frac{\sigma_{c i}}{\sigma_{c}}$ for most rocks falls in the range of 0.3 to 0.5 . Moreover, the relative and rootmean square errors between the calculated (Eq. 1) and 
observed $\mathrm{M}_{\mathrm{R}}$ at $\varepsilon_{\mathrm{a} \max }<1 \%$ were calculated. The relative error $(\varsigma, \%)$ for studied samples is between 0.28 and $25 \%$ and root-mean square error is $(\chi=50)$, while Palchik (2011) calculated the relative error is between 0.08 and $10.8 \%$ and the root-mean square error is 43.6. Furthermore, the relationships between deformation constants were investigated. Based on our analyses, there is correlation between tan and secant Young's modulus $\left(R^{2}=0.91\right)$, tan and secant modulus of rigidity $\left(R^{2}=0.90\right)$, tan and secant modulus ratio $\left(R^{2}=0.95\right)$, tan Young's modulus and rigidity modulus $\left(R^{2}=0.96\right)$, secant Young's modulus and rigidity modulus $\left(R^{2}=0.95\right)$, Tangant Modulus ratio $\left(M_{R t a n}\right)$ and Secant Modulus ratio $\left(M_{R s e c}\right)$ with the value of $\left(R^{2}=0.95\right)$. The estimated [Eqs. (10) and (14)] and observed stress-strain relations were plotted for all studied granitic rock samples. The values of the rootmean-square errors $(\chi)$, was also calculated for samples (based on Eq. (9)). For sample(a), this value is $2.3 \mathrm{MPa}$ and $1.91 \mathrm{MPa}$, for sample(b), this value is 18.71 MPa and 21.39 MPa, for sample(c), this value is 7.32 $\mathrm{MPa}$ and 4.97 $\mathrm{MPa}$, for sample(d), this value is 34.7 MPa and 21.87 MPa. Palchik (2019) observed a very good linear correlation $\left(0.983<R^{2}<0.99\right)$ between estimated and observed axial stresses for very strong $\left(\sigma_{c}>100 \mathrm{Mpa}\right)$ carbonate rocks, his results are in good agreement with our obtain results $\left(0.997<\mathrm{R}^{2}<0.999\right)$ for granitic rock samples.

\section{Conclusion}

From the results of this study, the following main conclusions are made:

- The mean value of $\left(M_{R \text { mean }}=439\right)$ for all granitic rock samples observed in this study and the mean value of $\left(M_{R \text { mean }}=420\right)$ obtained by Deere (1968) for limestone and dolomite and the mean value of $\left(\mathrm{M}_{\mathrm{R} \text { mean }}=380.5\right)$ obtained by Palchik (2011) for carbonate rock samples are similar. However, the range of $\left(\mathrm{M}_{\mathrm{R}}=326.42-597.42\right)$ obtained in this study is narrower than the range of $\left(\mathrm{M}_{\mathrm{R}}\right.$ = 250-700) obtained by Deere (1968) and the range of $\left(\mathrm{M}_{\mathrm{R}}=60-1600\right)$ obtained by Palchik (2011).

- The observation confirms that there is no general empirical correlation (with reliable $R^{2}$ ) between elastic modulus $(E)$ and uniaxial compressive strength $\left(\sigma_{\mathrm{c}}\right), \mathrm{M}_{\mathrm{R}}$ and maximum volumetric strain $\left(\varepsilon_{\mathrm{cd}}\right), \mathrm{M}_{\mathrm{R}}$ and crack damage stress $\sigma_{\mathrm{cd}}$.

- The analytical relationship (Eq. 1) between $\varepsilon_{\mathrm{a} \text { max }}$ and $M_{R}$ offered by Palchik (2011) for carbonate rock samples were investigated for granitic rock samples in this study. It is observed that this relationship can also be used for granitic rocks. The relative error $(\varsigma, \%)$ for studied samples is between 0.2 and $24.5 \%$ and root-mean square error is $(\chi=50)$. Compare the values with the result obtained by Palchik (2011) for carbonate rock samples, the relative error is between 0.08 and $10.8 \%$ and the root-mean square error is 43.6.

- The observed correlation between $\mathrm{M}_{\mathrm{R}}$ and $\varepsilon_{c d}$ for studied granitic rock sample is $\left(\mathrm{R}^{2}=0.20\right)$. Palchik (2011); however, found a good relationship $\left(R^{2}=0.85\right)$ between these two parameters for carbonate rock samples.

- A mathematical model proposed by Palchik (2019) for very strong $\left(\sigma_{\mathrm{c}}>100 \mathrm{MPa}\right)$ carbonate rocks based on Haldane's distribution function has a good predictive capability for the linear part of observed stress-strain relation of studied granitic rock samples; however, when it comes to nonlinearity behaviour there is a significant difference.

- Based on proposed mathematical model by Palchik (2019), there is a very good linear correlation between observed and estimated stresses for studied granitic rock samples with the value of $\mathrm{R}^{2}=0.99$.

Notably, for a more precise and fundamental description of the mechanical behaviour of rock, one should apply nonequilibrium continuum thermodynamics along the lines of Asszonyi et al. (2015) and beyond. These relationships can be used for determining the mechanical parameters of the rock mass, as well (Vásárhelyi and Kovács 2017).

Acknowledgements Open access funding provided by Budapest University of Technology and Economics (BME). This paper has been published with the permission of Public Limited Company for Radioactive Waste Management (PURAM). The Project presented in this article is supported by National Research, Development and Innovation Office NKFIH 124366 and NKFIH 124508 and the Hungarian-French Scientific Research Grant (No. 2018-2.1.13-TÉT-FR-201800012).

Open Access This article is licensed under a Creative Commons Attribution 4.0 International License, which permits use, sharing, adaptation, distribution and reproduction in any 
medium or format, as long as you give appropriate credit to the original author(s) and the source, provide a link to the Creative Commons licence, and indicate if changes were made. The images or other third party material in this article are included in the article's Creative Commons licence, unless indicated otherwise in a credit line to the material. If material is not included in the article's Creative Commons licence and your intended use is not permitted by statutory regulation or exceeds the permitted use, you will need to obtain permission directly from the copyright holder. To view a copy of this licence, visit http://creativecommons.org/licenses/by/4.0/.

\section{References}

Asszonyi C, Fülöp T, Ván P (2015) Distinguished rheological models for solids in the framework of a thermodynamical internal variable theory. Contin. Mech. Therm. 27(6):971-986. https://doi.org/10.1007/s00161-014-03923

Asszonyi C, Csatár A, Fülöp T (2016) Elastic, thermal expansion, plastic and rheological processes-theory and experiment. Period Polytech Civ Eng 60(4):591-601

Bieniawski ZT (1967) Mechanism of brittle fracture of rock. Int J Rock Mech Min Sci 4:395-430

Brace WF, Paulding BW, Scholz C (1966) Dilatancy in the fracture of crystalline rocks. Geophysics 71:3939-3953

Buda G (1985) Formation of Variscan collisional granitoids. Candidate thesis, Eötvös University, Budapest, Hungary. (in Hungarian)

Cieslik J (2014) Onset of crack initiation in uniaxial and triaxial compression tests of dolomite samples. Studia Geotechnica et Mechanica 36(1):23-27

Davarpanah M, Somodi G, Kovács L, Vásárhelyi B (2019) Complex analysis of uniaxial compressive tests of the Mórágy granitic rock formation (Hungary). Studia Geotechnica et Mechanica 41(1):21-32

Deere DU (1968) Geological considerations. In: Stagg KG, Zienkiewicz OC (eds) Rock mechanics in engineering practice. Wiley, London, pp 1-20

Deere D, Miller R (1966) Engineering classification and index properties for intact rock. Tech. Report No AFWL - TR-65116. Air Force Weapons Lab., Kirtland Air Base, New Mexico

Diederichs MS (2007) The 2003 Canadian geotechnical colloquium: mechanistic interpretation and practical application of damage and spalling prediction criteria for deep tunnelling. Can Geotech J 44:1082-1116

Eberhard TE, Stead D, Stimpson B (1999) Quantifying progressive pre-peak brittle fracture damage in rock during uniaxial compression. Int $\mathrm{J}$ Rock Mech Min Sci 36:361-380

Haldane JBS (1919) The combination of linkage values and the calculation of distances between the loci of linked factors. Genetics 8:299-309

Heo JS, Cho HK, Lee CI (2001) Measurement of acoustic emission and source location considering anisotropy of rock under triaxial compression. In: Sarkka P, Eloranta $\mathrm{P}$ (eds) Rock mechanics a challenge for society. Swets and Zeitlinger Lisse, Espoo, pp 91-96

Katz O, Reches Z (2004) Microfracturing, damage and failure of brittle granites. J Geophys Res 109(B1):1-13

Király E, Koroknai B (2004) The magmatic and metamorphic evolution of the north-eastern part of the Mórágy Block. Annual Rep. of Geol. Inst. of Hung. from 2003, pp 299-318

Martin CD (1993) Strength of massive Lac du Bonnet granite around underground openings. PhD thesis, Department of Civil and Geological Engineering, University of Manitoba, Winnipeg

Martin CD, Chandler NA (1994) The progressive fracture of Lac du Bonnet granite. Int J Rock Mech Min Sci 31:643-659

Ocak I (2008) Estimating the modulus of elasticity of the rock material from compressive strength and unit weight. J S Afr Inst Min Metall 108(10):621-629

Palchik V (2007) Use of stress-strain model based on Haldane's distribution function for prediction of elastic modulus. Int $\mathbf{J}$ Rock Mech Min Sci 44(4):514-524

Palchik V (2011) On the ratios between elastic modulus and uniaxial compressive strength of heterogeneous carbonate rocks. Rock Mech Rock Eng 44:121-128

Palchik V (2013) Is there link between the type of the volumetric strain curve and elastic constants, porosity, stress and strain characteristics. Rock Mech Rock Eng 46:315-326

Palchik V (2019) Simple stress-strain model of very strong limestones and dolomites for engineering practice. Geomech Geophys Geo-energy Geo-resour 6:1-12

Palmström A, Singh R (2001) The deformation modulus of rock masses-comparisons between in situ tests and indirect estimates. Tunn Undergr Space Tech 16:115-131

Pettitt WS, Young RP, Marsden JR (1998) Investigating themechanics of microcrack damage induced under true-triaxial unloading. In: Eurock 98, Society of Petroleum Engineering, p SPE 47319

Ramamurthy T, Madhavi LG, Sitharam TG (2017) Modulus ratio and joint factor concepts to predict rock mass response. Rock Mech Rock Eng 50:366-535

Ulusay R, Hudson JA (2007) The complete ISRM suggested methods for rock characterization, testing and monitoring: 1974-2006. ISRM Turkish National Group, Ankara

Vásárhelyi B (2005) Statistical analysis of the influence of water content on the strength of the Miocene limestone. Rock Mech Rock Eng 38:69-76

Vásárhelyi B, Davarpanah M (2018) Influence of water content on the mechanical parameters of the intact rock and rock mass. Period Polytech Civ Eng 62(4):1060-1066

Vásárhelyi B, Kovács D (2017) Empirical methods of calculating the mechanical parameters of the rock mass. Period Polytech Civ Eng 61(1):39-50

Vásárhelyi B, Kovács L, Kovács B (2013) Determining the failure envelope of intact granitic rocks from Bátaapáti. Geosci Eng 2(4):93-101

Publisher's Note Springer Nature remains neutral with regard to jurisdictional claims in published maps and institutional affiliations. 